\title{
Increasing crop productivity in coastal areas by proper management of potassium fertilizers
}

\author{
MG Kibria $^{1}$, MF Haque ${ }^{1}$, MS Islam ${ }^{2}$, MA Hoque ${ }^{{ }^{*}}$ \\ ${ }^{1}$ Department of Soil Science, Bangladesh Agricultural University, Mymensingh-2202, Bangladesh \\ ${ }^{2}$ Farm Management Division, Bangladesh Rice Research Institute, Gazipur, Bangladesh
}

\begin{abstract}
The field experiment was conducted to investigate the alleviation of the adverse effects of soil salinity in rice by efficient management of potassium fertilizers in coastal saline areas.The salt-sensitive (BRRI dhan28) and salttolerant (Binadhan-10) rice cultivars were used as test crops. The experiment was laid out in a randomized complete block design with three replications. There were thirteen treatment combinations viz. $\mathrm{T}_{0}$ (no $\mathrm{K}$ from MoP or SoP), $T_{1}$ ( $K_{100}$ from MoP at final land preparation), $T_{2}$ ( $K_{150}$ from MoP at final land preparation), $T_{3}$ ( $\mathrm{K}_{200}$ from MoP at final land preparation), $\mathrm{T}_{4}$ ( $\mathrm{K}_{100}$ from MoP in two splits), $\mathrm{T}_{5}$ ( $\mathrm{K}_{150}$ from MoP in two splits), $\mathrm{T}_{6}$ ( $\mathrm{K}_{200}$ from MoP in two splits), $\mathrm{T}_{7}$ ( $\mathrm{K}_{100}$ from SoP at final land preparation), $\mathrm{T}_{8}$ ( $\mathrm{K}_{150}$ from SoP at final land preparation), $T_{9}$ ( $\mathrm{K}_{200}$ from SoP at final land preparation), $T_{10}$ ( $\mathrm{K}_{100}$ from SoP in two splits), $T_{11}$ ( $\mathrm{K}_{150}$ from SoP in two splits) and $\mathrm{T}_{12}\left(\mathrm{~K}_{200}\right.$ from SoP in two splits). Muriate of potash (MoP) and sulphate of potash (SoP) were applied in two splits and during land preparation as per treatments. Binadhan-10 (salt-tolerant) rice producedhigher grain and straw yields than salt-sensitive (BRRI dhan28) one under saline conditions. Furthermore, application of potassium fertilizers resulted in significant increases growth, and grain and straw yields of both salt-sensitive and salt-tolerant rice cultivars under saline conditions. The nutrient (NPS) uptake and $\mathrm{K}^{+} / \mathrm{Na}^{+}$ratio increased in both rice cultivars by application of potassium fertilizers under saline conditions. The higher amount of yield as well as nutrient uptake of both rice cultivars was observed when SoP was applied either in land preparation or two split doses. The $\mathrm{K}^{+} / \mathrm{Na}^{+}$ratio was found to be higher in $\mathrm{T}_{9}$ and $\mathrm{T}_{12}$ treatments in salt-sensitive cultivar whereas $T_{2}$ and $T_{3}$ treatments showed higher $\mathrm{K}^{+} / \mathrm{Na}^{+}$ratio in grain and straw of salttolerant rice cultivar, respectively. Therefore, the present study suggests that rice productioncould be improved in saline areas through application of higher doses of potassium fertilizers particularly split application of sulphate of potash.
\end{abstract}

Key words: Muriate of potash, sulphate of potash, rice yield, nutrient uptake

Progressive Agriculturists. All rights reserve

*Corresponding Author: shamimabari@gmail.com

\section{Introduction}

Soil salinity is a major concern to agriculture all over the world because it affects almost all plant functions. More than $6 \%$ of the world's land and one third of the world's irrigated land are significantly affected by soil salinity (Flowers and Yeo, 1995; FAO, 2008). Moreover, soil salinizationdue to irrigation is becoming increasingly detrimental to agriculture. Salinity imposes both ionictoxicity and osmotic stress to plants, leading to nutritiondisorder and oxidative stress (Hasegawa et al., 2000; Zhu, 2003). Salt stress disturbs cytoplasmic $\mathrm{K}^{+} / \mathrm{Na}^{+}$homeostasis, causing an increase in $\mathrm{Na}^{+}$to $\mathrm{K}^{+}$ratio in the cytosol (Zhu, 2003). It has been reported that salt stress causes increased uptake of $\mathrm{Na}^{+}$and $\mathrm{Cl}^{-}$, and decreased uptake of essential cations particularly $\mathrm{K}^{+}$(Khan et al., 2003). Minimizing $\mathrm{Na}^{+}$uptake and preventing $\mathrm{K}^{+}$losses from 
the cell help in maintaining $\mathrm{K}^{+} / \mathrm{Na}^{+}$ratio optimum for plant metabolism in the cytoplasm under salt-stress conditions.

Agriculture is the most important sector of Bangladesh's economy. Climate change is widely recognized as the most serious environmental threat to agriculture. Climate change causes sea level rise and that affects the coastal areas of Bangladesh. The coastal areas of Bangladesh cover more than $30 \%$ of the cultivable lands of the country. About 1.06 million hectares of arable lands are affected by salinity (SRDI, 2010). The area under salinity is increasing with time (from $0.83 \mathrm{~m}$ ha to $1.06 \mathrm{~m}$ ha in 36 years, SRDI, 2010) due to rise in sea water level with increased global temperature. Increased soil salinity due to climate change would significantly reduce food grain production. Soil salinization is a major process of land degradation that decreases soil fertility and crop productivity. There is a report that coastal regions of Bangladesh are quite lower in soil fertility (Haque, 2006). Plants have developed a wide range of mechanisms to resist a variety of stressed conditions. Increasing evidence suggests that mineral nutrients particularly $\mathrm{K}$ play a critical role in plant stress resistance (Cakmak, 2005; Marschner, 2012). Salt tolerance is directly associated with $\mathrm{K}$ contents because of its involvement in osmotic regulation and competition with Na. Plant salt tolerance requires not only adaptation to $\mathrm{Na}^{+}$toxicity but also the acquisition of abundant $\mathrm{K}^{+}$whose uptake by the plant cell is affected by high external $\mathrm{Na}^{+}$ concentrations (Zhang et al., 2010).

Potassium is essential for many physiological processes such as carbon assimilation, photosynthesis, protein synthesis, enzyme activation, stomatal movement, and translocation of organic and inorganic nutrients from soil to plant (Marschner, 2012). However, potassium fertilizers such as muriate of potash $(\mathrm{KCl})$ and sulphate of potash $\left(\mathrm{K}_{2} \mathrm{SO}_{4}\right)$ are found to be effective in the amelioration of saline soils. Potash fertilizer has an added advantage under soil salinity as it lowers down $\mathrm{Na}$ uptake by plants and increases $\mathrm{K}$ uptake, thereby protecting crops from the detrimental effects of Na. There are increasing evidences that application of potassium fertilizers reduces the adverse effects of salinity in a variety of crops including rice (Idrees $e t$ al., 2004; Zayed et al.,2007; Maqsood et al., 2008; Jamshid 2010; Ebrahimi et al., 2012; Wakeel, 2013). Additionally, sulphur present in $\mathrm{K}_{2} \mathrm{SO}_{4}$ contributes to the reduction of soil salinity.

Unfortunately no systematic information is available in Bangladesh about the role of $\mathrm{K}$ in alleviating the detrimental effects of soil salinity in crop plants although its role in increasing crop productivity is widely documented. Very recently, our experiments in coastal areas have demonstrated that rice cultivation is profitable with proper management of saline soils. Maintaining an optimum $\mathrm{K}$ nutritional status is essential for plant resistance to salt stress. Therefore, the improvement of crop production in saline soils could be achieved by balanced fertilization particularly efficient management of potassium fertilizers with suitable high yielding crop varieties.

\section{Materials and Methods}

Field experiment: The field experiment was carried out at BRRI station, Sonagazi, Feni. The experiment was laid out in a randomized complete block design with three replications. Seedlings of salt-sensitive (BRRI dhan28) and salt-tolerant (Binadhan-10) rice cultivars were transplanted in the experimental fields. Potassium fertilizers such as muriate of potash (MoP) and sulphate of potash (SoP) were applied to the experimental plots as per treatments. Full amounts of $\mathrm{MoP}$ and SoP were applied at the time of final land preparation. MoP and SoP were also applied in two split doses; first dose at final land preparation and second dose at maximum tillering stage. The land was prepared by repeated ploughing and cross ploughing followed by laddering. There were different treatment combinations consisting of different doses of $\mathrm{MoP}$ and SoP including control as the followings:

$\mathrm{T}_{0}=$ Control (no $\mathrm{K}$ from MoP or SoP)

$\mathrm{T}_{1}=100 \%$ of the recommended dose of $\mathrm{K}$ from

MoP (at final land preparation)

$\mathrm{T}_{2}=150 \%$ of the recommended dose of $\mathrm{K}$ from

$\mathrm{MoP}$ (at final land preparation)

$\mathrm{T}_{3}=200 \%$ of the recommended dose of $\mathrm{K}$ from MoP (at final land preparation) 
$\mathrm{T}_{4}=100 \%$ of the recommended dose of $\mathrm{K}$ from MoP (in two splits)

$\mathrm{T}_{5}=150 \%$ of the recommended dose of $\mathrm{K}$ from MoP (in two splits)

$\mathrm{T}_{6}=200 \%$ of the recommended dose of $\mathrm{K}$ from MoP (in two splits)

$\mathrm{T}_{7}=100 \%$ of the recommended dose of $\mathrm{K}$ from SoP (at final land preparation)

$\mathrm{T}_{8}=150 \%$ of the recommended dose of $\mathrm{K}$ from SoP (at final land preparation)

$\mathrm{T}_{9}=200 \%$ of the recommended dose of $\mathrm{K}$ from SoP (at final land preparation)

$\mathrm{T}_{10}=100 \%$ of the recommended dose of $\mathrm{K}$ from SoP (in two splits)

$\mathrm{T}_{11}=150 \%$ of the recommended dose of $\mathrm{K}$ from SoP (in two splits)

$\mathrm{T}_{12}=200 \%$ of the recommended dose of $\mathrm{K}$ from SoP (in two splits)

Fertilization and intercultural operations: All treatments including control received recommended doses of N, P, S and Zn fertilizers (BARC, 2012). Potassium fertilizers were applied in the experimental pots as per treatments. Irrigation, intercultural operations and other management practices were performed as and when required. The crops were harvested at full maturity. Grain and straw yields were recorded.

Laboratory analysis: Chemical analysis of grain and straw samples was performed in the Department of Soil Science, BAU. The collected grain and straw samples were dried in an oven at $65^{\circ} \mathrm{C}$ for about 48 hours and then ground by a grinding machine. After digesting the samples total $\mathrm{N}$ content of grain and straw was determined following micro-Kjeldahl method. The grain and straw samples were digested for determination of $\mathrm{P}, \mathrm{K}, \mathrm{S}$ and $\mathrm{Na}$ contents and their concentration was determined following standard method as described by Khanamet al. (2001).

Statistical analysis: Data were analyzed statistically by ANOVA. The significance of differences between mean values was evaluated by Duncan's Multiple Range Test (DMRT). The software package, MSTATC was followed for statistical analysis.

\section{Results}

Growth and yields of rice: Salinity caused reductions in growth and yield components of both salt-sensitive and salt-tolerant rice cultivars while potassium fertilizers improved the growth and yield components of both cultivars under saline conditions (data not shown). Salinity also caused a significant reduction in grain and straw yields of both saltsensitive and salt-tolerant rice cultivars (Figure 1 and 2). Salt-tolerant cultivar (Binadhan-10) produced higher grain yield than salt-sensitive cultivar (BRRI dhan28) under salinity stress.

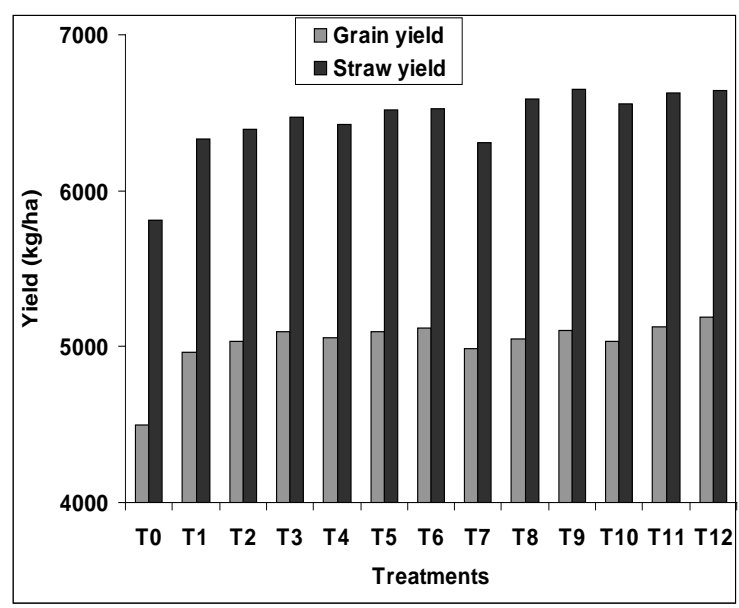

Figure 1: Grain and straw yields of BRRI dhan28 influenced by potassium fertilizers under soil salinity

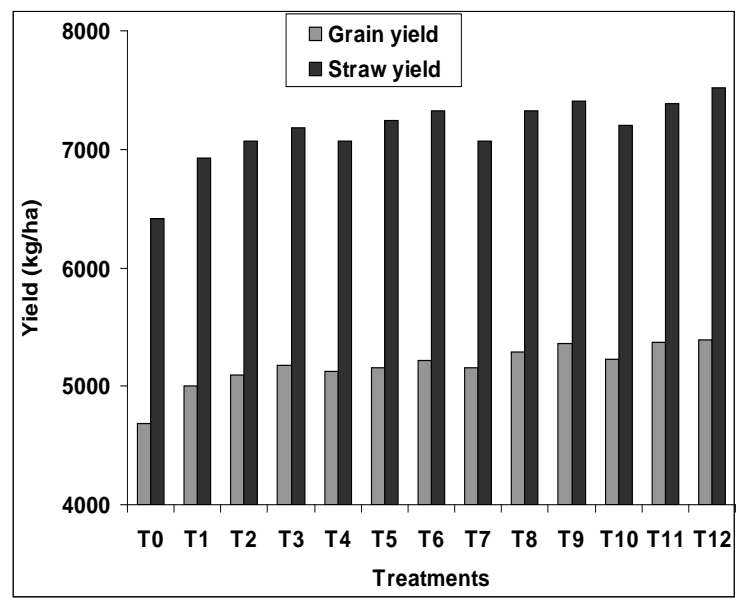

Figure 2: Grain and straw yields of Binadhan-10 influenced by potassium fertilizers under soil salinity 
Application of potassium fertilizers remarkably increased grain and straw yields of both rice cultivars. We also observed that sulphate of potash fertilizer showed better performances in producing grain and straw yields under soil salinity conditions. Results also indicate that effect of sulphate of potash was more prominent in salt-tolerant cultivar.

$\mathrm{K}^{+} / \mathrm{Na}^{+}$ratio in rice: We measured $\mathrm{K}^{+} / \mathrm{Na}^{+}$ratio in both salt-sensitive and salt-tolerant rice genotypes (Table 1). Salt-tolerant cultivar showed higher $\mathrm{K}^{+} / \mathrm{Na}^{+}$ratio than salt-sensitive cultivar. Application of potassium fertilizers increased $\mathrm{K}^{+} / \mathrm{Na}^{+}$ratio in rice during soil salinity in both of the varieties. In case of BRRI dhan $28, \mathrm{~K}^{+} / \mathrm{Na}^{+}$ratio in both grain and straw samples was low due to salt stress in control. Application of potassium fertilizer significantly increased the $\mathrm{K}^{+} / \mathrm{Na}^{+}$ratio. From the Table 1, it was found that $\mathrm{K}^{+} / \mathrm{Na}^{+}$ratio in grain samples was the highest in those treatments where sulphate of potash was applied as mentioned in treatments. Sulphate of potash application showed higher $\mathrm{K}^{+} / \mathrm{Na}^{+}$ratio compared to $\mathrm{MoP}$ in straw samples as well.The salttolerant rice variety (Binadhan-10) also showed significant difference in $\mathrm{K}^{+} / \mathrm{Na}^{+}$ratio (Table 1). The highest $\mathrm{K}^{+} / \mathrm{Na}^{+}$ratio in grain and straw samples was obtained in Binadhan-10 when muriate of potash was applied.

Table 1: Effect of potassium fertilizers on $\mathrm{K}^{+} / \mathrm{Na}^{+}$ ratio in two rice cultivars (BRRI dhan 28 and Bina dhan 10)

\begin{tabular}{|c|c|c|c|c|}
\hline \multirow{2}{*}{ Treatment } & \multicolumn{2}{|c|}{ BRRI dhan 28 } & \multicolumn{2}{c|}{ Bina dhan 10 } \\
\cline { 2 - 5 } & Grain & Straw & Grain & Straw \\
\hline $\mathrm{T}_{0}$ & $5.00 \mathrm{~h}$ & $2.56 \mathrm{e}$ & $7.64 \mathrm{~h}$ & $2.88 \mathrm{e}$ \\
\hline $\mathrm{T}_{1}$ & $7.00 \mathrm{~g}$ & $3.45 \mathrm{~d}$ & $9.20 \mathrm{~b}$ & $4.62 \mathrm{c}$ \\
\hline $\mathrm{T}_{2}$ & $7.90 \mathrm{e}$ & $3.58 \mathrm{~cd}$ & $9.72 \mathrm{a}$ & $4.65 \mathrm{c}$ \\
\hline $\mathrm{T}_{3}$ & $8.00 \mathrm{e}$ & $3.68 \mathrm{bc}$ & $8.33 \mathrm{f}$ & $5.33 \mathrm{a}$ \\
\hline $\mathrm{T}_{4}$ & $7.50 \mathrm{f}$ & $3.51 \mathrm{~cd}$ & $8.50 \mathrm{ef}$ & $4.55 \mathrm{c}$ \\
\hline $\mathrm{T}_{5}$ & $9.15 \mathrm{bc}$ & $3.58 \mathrm{~cd}$ & $8.00 \mathrm{~g}$ & $4.98 \mathrm{~b}$ \\
\hline $\mathrm{T}_{6}$ & $9.15 \mathrm{bc}$ & $3.50 \mathrm{~d}$ & $8.56 \mathrm{e}$ & $4.96 \mathrm{~b}$ \\
\hline $\mathrm{T}_{7}$ & $8.68 \mathrm{~d}$ & $3.80 \mathrm{~b}$ & $9.04 \mathrm{bcd}$ & $4.48 \mathrm{c}$ \\
\hline $\mathrm{T}_{8}$ & $8.88 \mathrm{~cd}$ & $4.32 \mathrm{a}$ & $9.04 \mathrm{bcd}$ & $4.48 \mathrm{c}$ \\
\hline $\mathrm{T}_{9}$ & $9.72 \mathrm{a}$ & $4.28 \mathrm{a}$ & $9.06 \mathrm{bc}$ & $5.04 \mathrm{~b}$ \\
\hline $\mathrm{T}_{10}$ & $9.25 \mathrm{~b}$ & $3.62 \mathrm{~cd}$ & $8.98 \mathrm{~cd}$ & $4.05 \mathrm{~d}$ \\
\hline $\mathrm{T}_{11}$ & $9.70 \mathrm{a}$ & $3.56 \mathrm{~cd}$ & $8.33 \mathrm{f}$ & $4.46 \mathrm{c}$ \\
\hline $\mathrm{T}_{12}$ & $9.80 \mathrm{a}$ & $3.83 \mathrm{~b}$ & $8.86 \mathrm{~d}$ & $4.88 \mathrm{~b}$ \\
\hline $\mathrm{SE}( \pm)$ & 0.109 & 0.051 & 0.061 & 0.068 \\
\hline
\end{tabular}

Nutrient uptake by rice plants: In case of BRRI dhan28, nutrient uptake in both grain and straw samples was low due to salt stress. Application of potassium fertilizer increased the NPS uptake significantly. Nutrient content was higher in grain samples compared to straw samples. From the Table 2 , it was found that nutrient uptake in grain and straw samples were highest in $\mathrm{T}_{9}(200 \%$ of the recommended dose of $\mathrm{K}$ from SoP at final land preparation) and $\mathrm{T}_{12}$ (200\% of the recommended dose of $\mathrm{K}$ from SoP at two splits) among the treatments. Application of potassium from MoP fertilizer was also found to be helpful for ameliorating the salinity problem. So, the results suggest that SoP application showed higher nutrient uptake compared to MoP. Total N, P and S uptake was also found higher in these two treatments.

The salt-tolerant rice variety (Binadhan-10) also showed the similar trend as the sensitive one (Table 3). The highest nutrient uptake (NPS) was obtained in Binadhan-10 when sulphate of potash was applied in two splits $\left(\mathrm{T}_{12}\right)$ compared to basal application $\left(\mathrm{T}_{9}\right)$. Total nutrient uptake by Binadhan-10 was also higher when sulphate of potash was applied in two splits compared to basal application of SoP and other treatments. Here it was found that salt-tolerant variety (Binadhan-10) showed higher uptake of essential nutrients like nitrogen, potassium and phosphorus due to application of potassium from SoP fertilizer compared to the salt-sensitive one (BRRI dhan 28) under salt stress.

\section{Discussion}

Salinity caused a significant reduction in grain and straw yield of both BRRI dhan 28 and Binadhan- 10 . Efficient management of potash fertilizers increased both grain and straw yield where sulphate of potash showed better yield performance than muriate of potash (Figure 1 and 2). It has also been reported that application of potash fertilizer reduces the adverse effects of salinity in sugarcane (Idrees et al., 2004). Inorganic amendments with sulphate of potash (SoP) performed better in producing growth and yield of both rice cultivars during salinity conditions compared to muriate of potash (MoP). Mehdi (2007) also found the similar result indicating that potassium 
fertilizer application increased both the grain and straw yield of both varieties but higher grain yield was observed in salt tolerant variety under salt stress.
The $\mathrm{K}^{+} / \mathrm{Na}^{+}$ratio reduced in both rice cultivars and potash fertilizers application showed an increase in $\mathrm{K}^{+} / \mathrm{Na}^{+}$ratio which helps plants to tolerate salinity.

Table 2. Effect of potassium fertilizer on nutrient uptake by grain and straw of BRRI dhan28 under saline condition

\begin{tabular}{|c|l|l|l|l|l|l|l|l|l|}
\hline \multirow{2}{*}{ Treatment } & \multicolumn{3}{|c|}{ N uptake (kg ha-1 } & \multicolumn{3}{c|}{ P uptake (kg ha $\left.{ }^{-1}\right)$} & \multicolumn{3}{c|}{ S uptake (kg ha $\left.{ }^{-1}\right)$} \\
\cline { 2 - 10 } & Grain & Straw & Total & Grain & Straw & \multicolumn{1}{|c|}{ Total } & Grain & Straw & Total \\
\hline $\mathrm{T}_{0}$ & $49.45 \mathrm{~g}$ & $31.97 \mathrm{e}$ & $81.42 \mathrm{f}$ & $11.14 \mathrm{~d}$ & $8.42 \mathrm{~d}$ & $19.56 \mathrm{~g}$ & $6.23 \mathrm{c}$ & $8.30 \mathrm{~d}$ & $14.53 \mathrm{~d}$ \\
\hline $\mathrm{T}_{1}$ & $56.62 \mathrm{f}$ & $39.26 \mathrm{~d}$ & $95.88 \mathrm{e}$ & $12.32 \mathrm{c}$ & $9.62 \mathrm{c}$ & $21.94 \mathrm{f}$ & $6.90 \mathrm{~b}$ & $9.88 \mathrm{c}$ & $16.78 \mathrm{c}$ \\
\hline $\mathrm{T}_{2}$ & $57.35 \mathrm{ef}$ & $38.35 \mathrm{~d}$ & $95.70 \mathrm{e}$ & $12.50 \mathrm{bc}$ & $9.65 \mathrm{c}$ & $22.15 \mathrm{def}$ & $6.95 \mathrm{~b}$ & $10.09 \mathrm{bc}$ & $17.04 \mathrm{c}$ \\
\hline $\mathrm{T}_{3}$ & $59.10 \mathrm{~cd}$ & $41.41 \mathrm{c}$ & $100.52 \mathrm{~cd}$ & $12.70 \mathrm{abc}$ & $10.22 \mathrm{abc}$ & $22.92 \mathrm{bcde}$ & $7.08 \mathrm{~b}$ & $10.30 \mathrm{abc}$ & $17.38 \mathrm{bc}$ \\
\hline $\mathrm{T}_{4}$ & $59.64 \mathrm{~cd}$ & $38.56 \mathrm{~d}$ & $98.20 \mathrm{de}$ & $12.38 \mathrm{c}$ & $9.64 \mathrm{c}$ & $22.02 \mathrm{f}$ & $7.01 \mathrm{~b}$ & $9.88 \mathrm{c}$ & $16.89 \mathrm{c}$ \\
\hline $\mathrm{T}_{5}$ & $60.14 \mathrm{bc}$ & $41.72 \mathrm{bc}$ & $101.86 \mathrm{~cd}$ & $12.80 \mathrm{abc}$ & $10.15 \mathrm{abc}$ & $22.95 \mathrm{bcd}$ & $7.04 \mathrm{~b}$ & $10.01 \mathrm{bc}$ & $17.05 \mathrm{c}$ \\
\hline $\mathrm{T}_{6}$ & $61.48 \mathrm{~b}$ & $41.75 \mathrm{bc}$ & $103.23 \mathrm{bc}$ & $12.70 \mathrm{abc}$ & $9.96 \mathrm{bc}$ & $22.66 \mathrm{cdef}$ & $7.02 \mathrm{~b}$ & $9.78 \mathrm{c}$ & $16.80 \mathrm{c}$ \\
\hline $\mathrm{T}_{7}$ & $58.40 \mathrm{de}$ & $37.84 \mathrm{~d}$ & $96.24 \mathrm{e}$ & $12.52 \mathrm{bc}$ & $9.60 \mathrm{c}$ & $22.12 \mathrm{ef}$ & $6.88 \mathrm{~b}$ & $10.40 \mathrm{abc}$ & $17.28 \mathrm{bc}$ \\
\hline $\mathrm{T}_{8}$ & $60.10 \mathrm{bc}$ & $41.50 \mathrm{c}$ & $101.60 \mathrm{~cd}$ & $13.03 \mathrm{ab}$ & $10.21 \mathrm{abc}$ & $23.24 \mathrm{abc}$ & $7.07 \mathrm{~b}$ & $10.20 \mathrm{abc}$ & $17.27 \mathrm{bc}$ \\
\hline $\mathrm{T}_{9}$ & $63.76 \mathrm{a}$ & $43.21 \mathrm{ab}$ & $106.97 \mathrm{ab}$ & $13.16 \mathrm{a}$ & $10.43 \mathrm{abc}$ & $23.59 \mathrm{ab}$ & $7.10 \mathrm{~b}$ & $10.44 \mathrm{abc}$ & $17.54 \mathrm{bc}$ \\
\hline $\mathrm{T}_{10}$ & $58.40 \mathrm{de}$ & $42.62 \mathrm{abc}$ & $101.02 \mathrm{~cd}$ & $12.63 \mathrm{abc}$ & $10.28 \mathrm{abc}$ & $22.91 \mathrm{bcde}$ & $7.10 \mathrm{~b}$ & $10.18 \mathrm{abc}$ & $17.28 \mathrm{bc}$ \\
\hline $\mathrm{T}_{11}$ & $59.48 \mathrm{~cd}$ & $42.40 \mathrm{abc}$ & $101.88 \mathrm{~cd}$ & $13.02 \mathrm{ab}$ & $10.74 \mathrm{ab}$ & $23.76 \mathrm{a}$ & $7.22 \mathrm{ab}$ & $10.73 \mathrm{ab}$ & $17.95 \mathrm{ab}$ \\
\hline $\mathrm{T}_{12}$ & $64.90 \mathrm{a}$ & $43.82 \mathrm{a}$ & $108.72 \mathrm{a}$ & $13.08 \mathrm{ab}$ & $10.82 \mathrm{a}$ & $23.90 \mathrm{a}$ & $7.54 \mathrm{a}$ & $10.84 \mathrm{a}$ & $18.38 \mathrm{a}$ \\
\hline $\mathrm{SE}( \pm)$ & 0.489 & 0.461 & 1.37 & 0.178 & 0.249 & 0.248 & 0.128 & 0.221 & 0.236 \\
\hline
\end{tabular}

Table 3. Effect of potassium fertilizer on nutrient uptake by grain and straw of Binadhan-10 under saline condition

\begin{tabular}{|c|c|c|c|c|c|c|c|c|c|}
\hline \multirow{2}{*}{ Treatment } & \multicolumn{3}{|c|}{ N uptake } & \multicolumn{3}{c|}{ P uptake } & \multicolumn{3}{c|}{ S uptake } \\
\cline { 2 - 10 } & Grain & Straw & Total & Grain & Straw & Total & Grain & Straw & Total \\
\hline $\mathrm{T}_{0}$ & $56.76 \mathrm{f}$ & $35.27 \mathrm{f}$ & $92.0 \mathrm{~g}$ & $12.30 \mathrm{~d}$ & $10.08 \mathrm{~d}$ & $22.4 \mathrm{~g}$ & $6.94 \mathrm{e}$ & $9.36 \mathrm{~h}$ & $16.3 \mathrm{~g}$ \\
\hline $\mathrm{T}_{1}$ & $64.04 \mathrm{de}$ & $42.90 \mathrm{e}$ & $106.9 \mathrm{f}$ & $14.40 \mathrm{c}$ & $10.54 \mathrm{~cd}$ & $24.9 \mathrm{f}$ & $7.88 \mathrm{~d}$ & $10.68 \mathrm{f}$ & $18.6 \mathrm{~d}-\mathrm{f}$ \\
\hline $\mathrm{T}_{2}$ & $64.20 \mathrm{de}$ & $42.44 \mathrm{e}$ & $106.6 \mathrm{f}$ & $14.52 \mathrm{bc}$ & $10.75 \mathrm{~cd}$ & $25.3 \mathrm{ef}$ & $8.05 \mathrm{~cd}$ & $10.90 \mathrm{def}$ & $18.9 \mathrm{~d}-\mathrm{f}$ \\
\hline $\mathrm{T}_{3}$ & $66.25 \mathrm{c}$ & $45.95 \mathrm{~d}$ & $112.2 \mathrm{de}$ & $15.01 \mathrm{abc}$ & $11.34 \mathrm{abc}$ & $26.3 \mathrm{~d}$ & $8.10 \mathrm{c}$ & $10.06 \mathrm{~g}$ & $18.2 \mathrm{f}$ \\
\hline $\mathrm{T}_{4}$ & $65.60 \mathrm{~cd}$ & $42.40 \mathrm{e}$ & $108.0 \mathrm{f}$ & $14.96 \mathrm{abc}$ & $10.60 \mathrm{~cd}$ & $25.6 \mathrm{e}$ & $8.14 \mathrm{c}$ & $11.02 \mathrm{cde}$ & $19.2 \mathrm{~b}-\mathrm{e}$ \\
\hline $\mathrm{T}_{5}$ & $66.47 \mathrm{c}$ & $46.34 \mathrm{~cd}$ & $112.8 \mathrm{de}$ & $15.14 \mathrm{abc}$ & $11.30 \mathrm{bc}$ & $26.4 \mathrm{~d}$ & $8.14 \mathrm{c}$ & $11.28 \mathrm{c}$ & $19.4 \mathrm{~b}-\mathrm{d}$ \\
\hline $\mathrm{T}_{6}$ & $67.25 \mathrm{c}$ & $47.62 \mathrm{bc}$ & $114.9 \mathrm{c}-\mathrm{e}$ & $15.01 \mathrm{abc}$ & $11.20 \mathrm{bc}$ & $26.2 \mathrm{~d}$ & $8.23 \mathrm{bc}$ & $11.60 \mathrm{~b}$ & $19.8 \mathrm{a}-\mathrm{c}$ \\
\hline $\mathrm{T}_{7}$ & $63.80 \mathrm{e}$ & $42.42 \mathrm{e}$ & $106.2 \mathrm{f}$ & $14.47 \mathrm{bc}$ & $10.74 \mathrm{~cd}$ & $25.2 \mathrm{ef}$ & $8.06 \mathrm{c}$ & $10.74 \mathrm{ef}$ & $18.8 \mathrm{~d}-\mathrm{f}$ \\
\hline $\mathrm{T}_{8}$ & $65.62 \mathrm{~cd}$ & $46.14 \mathrm{~cd}$ & $111.8 \mathrm{e}$ & $15.24 \mathrm{abc}$ & $11.35 \mathrm{abc}$ & $26.6 \mathrm{~cd}$ & $8.20 \mathrm{bc}$ & $11.06 \mathrm{~cd}$ & $19.3 \mathrm{~b}-\mathrm{e}$ \\
\hline $\mathrm{T}_{9}$ & $67.25 \mathrm{c}$ & $48.17 \mathrm{ab}$ & $115.4 \mathrm{~cd}$ & $15.32 \mathrm{ab}$ & $11.64 \mathrm{ab}$ & $26.9 \mathrm{bc}$ & $8.38 \mathrm{ab}$ & $10.04 \mathrm{~g}$ & $18.4 \mathrm{ef}$ \\
\hline $\mathrm{T}_{10}$ & $69.56 \mathrm{~b}$ & $46.80 \mathrm{bcd}$ & $116.4 \mathrm{c}$ & $15.08 \mathrm{abc}$ & $11.26 \mathrm{bc}$ & $26.3 \mathrm{~d}$ & $8.05 \mathrm{~cd}$ & $10.96 \mathrm{def}$ & $19.0 \mathrm{c}-\mathrm{f}$ \\
\hline $\mathrm{T}_{11}$ & $73.08 \mathrm{a}$ & $47.28 \mathrm{bcd}$ & $120.4 \mathrm{~b}$ & $15.27 \mathrm{abc}$ & $11.96 \mathrm{ab}$ & $27.2 \mathrm{ab}$ & $8.38 \mathrm{ab}$ & $11.66 \mathrm{~b}$ & $20.0 \mathrm{ab}$ \\
\hline $\mathrm{T}_{12}$ & $73.85 \mathrm{a}$ & $49.60 \mathrm{a}$ & $123.5 \mathrm{a}$ & $15.52 \mathrm{a}$ & $12.18 \mathrm{a}$ & $27.7 \mathrm{a}$ & $8.51 \mathrm{a}$ & $11.96 \mathrm{a}$ & $20.5 \mathrm{a}$ \\
\hline $\mathrm{SE}( \pm)$ & 0.489 & 0.461 & 1.37 & 0.178 & 0.249 & 0.248 & 0.128 & 0.221 & 0.236 \\
\hline
\end{tabular}


Higher $\mathrm{K}^{+} / \mathrm{Na}^{+}$ratio was observed in salt tolerant cultivar than the sensitive one (Table 1). Almodares et al. (2014) also found that $\mathrm{K}^{+} / \mathrm{Na}^{+}$ratio increased in salt tolerant cultivars and decreased in salt sensitive ones, it seems that this ratio among other parameters is a better indicator for selection of salt tolerant cultivars. Safaa et al. (2013) also found that potassium application could play an important role in alleviation of injury of salinity in both salt-sensitive and salt-tolerant cultivars, and higher $\mathrm{K}^{+} / \mathrm{Na}^{+}$ratio was observed in tolerant varieties compared to the sensitive one.

The higher uptake of essential nutrientssuch as nitrogen, phosphorus and sulphurwas observed in both salt-sensitive and salt tolerant rice cultivars (Table 2 and 3) due to application of potash fertilizers. Abida et al. (2014) also found the same result that the application of $\mathrm{K}_{2} \mathrm{SO}_{4}$ increased the uptake of essential nutrients like nitrogen, potassium, calcium, magnesium and phosphorus in saline soils. Similar result was also found by Safaa et al. (2013) indicating that salinity stress decreased nutrient uptake rate and potassium fertilizer application was found to be helpful for ameliorating the salinity problem. Yagmur et al. (2007) also reported that potassium application had positive effects on salinity and alleviated negative effects of salinity on wheat seedling. Potassium application significantly increased total nutrient (nitrogen, phosphorus, sulphur and potassium) uptake by wheat plants under salt stress. Sara et al. (2004) also found the similar result. Abida et al. (2014) also found the same result that the application of $\mathrm{K}_{2} \mathrm{SO}_{4}$ increased the uptake of essential nutrients like nitrogen, potassium, calcium, magnesium and phosphorus in saline soils.

\section{Conclusion}

It can be concluded that Binadhan-10 (salt-tolerant) cultivar comparatively produced higher grain yield than salt-sensitive (BRRI dhan28). The nutrient uptake and $\mathrm{K}^{+} / \mathrm{Na}^{+}$ratio increased in the saltsensitive and salt-tolerant rice varieties under saline condition due to application of potassium fertilizers. The present study suggests that rice crop production could be profitable in coastal saline areas of southern Bangladesh through application of potassium fertilizers. Moreover, sulphate of potash showed better performances in aspect of rice yield than muriate of potash.

\section{Acknowledgements}

The authors aregrateful to Ministry of Science and Technology, Government of Peoples Republic of Bangladesh for financial support of this research work.

\section{References}

Abida K, Munazza G (2014). Effect of potassium sulphate on the growth and uptake of nutrients in wheat (Triticumaestivum L.) under salt stressed conditions.Journal of Agricultural Science,6(8): 209-213.

Almodares A, Hadi MR, Kholdebarin B, Samedani B,Kharazian ZA (2014). The response of sweet sorghum cultivars to salt stress and accumulation of $\mathrm{Na}^{+}, \mathrm{Cl}^{-}$and $\mathrm{K}^{+}$ions in relation to salinity. Journal of Environmental Biology,35(4): 733-739.

BARC (2012).Fertilizer Recommendation Guide2012.Bangladesh Agricultural Research Council, Farmgate, Dhaka.

Begum F, Sadeque A, Khatun F, Alam MK (2007).Suitability of different cultivars of wheat and maize for cultivation in coastal area ofNoakhali.Bangladesh Journal of Scientific and Industrial Research, 42:361-365.

Cakmak I (2005).The role of potassium in alleviating detrimental effects of abiotic stresses in plants. Journal of Plant Nutrition and Soil Science, 168:521-530.

Ebrahimi FR, Rahdari P, Vahed HS, Shahinrokhsar P (2012).Rice response to different methods of potassium fertilization in salinity stress condition. International Journal of Agriculture and Crop Science, 4: 798-802.

FAO (2008).Land and Plant Nutrition Management Service. http://www.fao.org/ag/ agl/agll /spush. 
Flowers TJ, Yeo AR (1995). Breeding for salinity resistance in crop plants: where next? Australian Journal of Plant Physiology, 22:875-884.

Haque SA (2006).Salinity problems and crop production in coastal regions of Bangladesh.Pakistan Journal of Botany, 38:1359-1365.

Hasegawa PM,Bressan RA, Zhu JK, Bohnert HJ (2000).Plant cellular and molecular responses to high salinity.Annual Review of Plant Physiology and Plant Molecular Biology, 51:463-499.

Heidari M, Jamshid P (2010).Interaction between salinity and potassium on grain yield, carbohydrate content and nutrient uptake in pearl millet.ARPN Journal of Agriculture and Biological Science, 5: 39-46.

Idrees S, Qureshi MS, Ashraf MY, Hussain M, Naveed NH (2004).Influence of sulphate of potash and farmyard manure on sugarcane (Saccharumofficinaruml.) grown under salt stress. Pakistan Journal of Life and Social Sciences, 2:65-69.

Khan AA, Rao SA, McNeilly T (2003). Assessment of salinity tolerance based upon seedling root growth response function in maize (Zea mays L.). Euphetica, 131:81-89.

Khanam M, Rahman MM, Islam MR, IslamMR (2001). Effect of manures and fertilizers on the growth and yield of BRRI dhan30.Pakistan Journal of Biological Science, 4: 172-174.

Maqsood T, Akhtar J, Farooq MR, Haq MA, Saqib ZA (2008). Biochemical attributes of salt tolerant and salt sensitive maize cultivars to salinity and potassium nutrition. Pakistan Journal of Agricultural Science, 45:1-5.

Marschner P (2012).Marschner's Mineral Nutrition of Higher Plants, 3rd ed.; Academic Press: London, pp 178-189.
Mehdi SM, Sarfraz M, Shah SAA (2007). Response of wheat to applied supplemental potassium in saline sodicsoil. Journal of Biological Sciences, 7:823-826.

Safaa R, El-Lethy, Magdi T, Abdel H, Fatma R (2013).Effect of potassium application on wheat (Triticumaestivum L.) cultivars grown under salinity stress.World Applied Sciences Journal,26 (7): 840-850.

Sara Z, Ashraf MY, Sarwar G, Mahmood S, Kausar A, Ali I (2004).Variation in growth and ion uptake in salt tolerant and sensitive rice cultivars under NaClsalinity.Asian Journal of Plant Sciences,3:156-158.

SRDI (2010). SRMAF Project, Ministry of Agriculture, Bangladesh. pp 1-60.

Wakeel A (2013).Potassium-sodium interactions in soil and plant under saline-sodic conditions.Journal of Plant Nutrition and Soil Science, 176:344-354.

Yagmur M, Kaydan D, Okut N (2007).Alleviation of salinity stress during seed germination in wheat (TriticumaestivumL.) by potassium applications.Indian Journal of Agricultural Sciences, 77(6):379-82.

Zayed BA, Elkhoby WM, Shehata SM, Ammar MH (2007). Role of potassium application on the productivity of some inbred and hybrid rice varieties under newly reclaimed saline soils. African Crop Science Conference Proceeding, 8: 53-60.

Zhang JL, Flowers TJ, Wang SM (2010).Mechanisms of sodium uptake by roots of higher plants.Plant and Soil, 326:45-60.

Zhu JK (2003).Regulation of ion homeostasis under salt stress.Current Opinion in Plant Biology,6:441-445. 